\title{
A new locality record for Radfordiella desmodi Radovsky, 1967 (Mesostigmata: Macronyssidae) parasitizing the vampire bat in Brazil
}

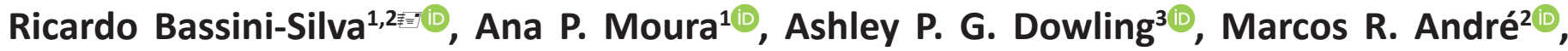 \\ Fernando de C. Jacinavicius ${ }^{1 \oplus}$, Darci M. Barros-Battesti ${ }^{2 \oplus}$
}

${ }^{1}$ Laboratório de Coleções Zoológicas, Instituto Butantan, São Paulo, SP, Brazil. ${ }^{2}$ Departamento de Patologia, Reprodução e Saúde Única, Faculdade de Ciências Agrárias e Veterinárias-UNESP, Jaboticabal, SP, Brazil. ${ }^{3}$ Department of Entomology \& Plant Pathology, University of Arkansas, Fayetteville, AR, USA.

拝=゙Corresponding author: ricardo.bassini@gmail.com

Edited by: Jose W. S. Melo (Guest Editor)

Received: November 05, 2021. Accepted: November 20, 2021. Published: December 09, 2021.

Abstract. Macronyssid mites are ectoparasites of reptiles, birds, and mammals (mainly bats). Out of 35 genera in this family, Radfordiella Fonseca, 1948 is a genus from the Neotropical region with six valid species, found parasitizing phyllostomid bats. Only Radfordiella desmodi Radovsky, 1967 and Radfordiella oudemansi Fonseca, 1948 have been registered in Brazil. The present study provides a new locality record for the species $R$. desmodi, microscopy images to aid in the identification, and a distribution map.

Keywords: mites, ectoparasites, Brazilian states, Chiroptera, Desmodus rotundus.

Mites of the family Macronyssidae Oudemans, 1936 are primarily ectoparasites of bats, although some genera parasitize reptiles, birds and other mammals (Radovsky 2010). Currently, there are approximately 35 genera and 241 valid species (Radovsky 2010; Orlova et al. 2017; Bassini-Silva et al. 2021; Gomes-Almeida \& Pepato 2021). The recent detection of Ehrlichia spp. (Ikeda et al. 2021) and Bartonella spp. (Ikeda et al. 2020) in macronyssid mites parasitizing bats from Brazil highlights the need for investigating the diversity and geographical distribution of these mites in Brazilian territory.

Radfordiella Fonseca, 1948 is a genus found in Neotropical areas and includes species that are ectoparasites of phyllostomid bats (Fonseca 1948; Radovsky 2010). There are currently six valid species, namely Radfordiella anourae Radovsky, Jones \& Phillips, 1971; Radfordiella carolliae Radovsky, 1967; Radfordiella desmodi Radovsky, 1967; Radfordiella monophylli Radovsky, Jones \& Phillips, 1971; Radfordiella oricola Radovsky, Jones \& Phillips, 1971; and Radfordiella oudemansi Fonseca, 1948 (Fonseca 1948; Radovsky 1967; Radovsky et al. 1971). According to a recent checklist (Bassini-Silva et al. 2021), only $R$. desmodi and $R$. oudemansi have been recorded in Brazil.

Radfordiella desmodi was recorded parasitizing the vampire bat, Desmodus rotundus (É. Geoffroy, 1810) (Chiroptera: Phyllostomidae), in the states of Mato Grosso do Sul, Minas Gerais and Rio de Janeiro (Azevedo et al. 2002; Silva et al. 2017; Lourenço et al. 2020). Two other records for this species include one in the state of Rio de Janeiro parasitizing Seba's short-tailed bat, Carollia perspicillata (L., 1758) (Chiroptera: Phyllostomidae) (Almeida et al. 2011), and another in the state of Minas Gerais, parasitizing the tropical big-eared brown bat Histiotus velatus (I. Geoffroy, 1824) (Chiroptera: Vespertilionidae) (Moras et al. 2013). In addition, R. desmodi has been found in Mexico, Colombia, Costa Rica, and Venezuela, parasitizing several phyllostomid bats, whereas it has been much more abundant and frequently found in D. rotundus, which apparently represents its preferred host (Saunders 1975; Rojas et al. 2008; Tarquino-Carbonell et al. 2015). Radfordiella oudemansi, the type species of the genus Radfordiella, was originally described from the state of São Paulo, southeastern Brazil, parasitizing D. rotundus (Fonseca 1948). In Brazil, there is only one other record for this species in the state of Mato Grosso do Sul, collected from the pale spear-nosed bat, Phyllostomus discolor Wagner, 1843 (Chiroptera:
Phyllostomidae) (Silva et al. 2017). Outside Brazil, R. oudemansi has been recorded in Venezuela (Saunders 1975), Mexico (Colín-Martínez et al. 2018), Trinidad (Zhang \& Uchikawa 1994), and in the US Virgin Islands (Reeves et al. 2006).

The vampire bat, $D$. rotundus, can be found from south-central Mexico to north-central Argentina, once this bat species has some preference for warmer regions, such as the Tropical and Subtropical Regions of the Americas (Simmons 2005). This species is one of the few species of bats that feed exclusively on vertebrate blood. Because of this, the bite of this animal can transmit pathogens (Brass 1994; Lord 1992). Thus, in Brazil, some institutions collect or monitor this bat species, such as Vector Control Management, situated in the Araraquara Municipality, state of São Paulo, which received a specimen of $D$. rotundus infested by mites. After handling and caring for the animal, its caregivers observed mites on the animal's skin, and immediately these mites were collected and sent to the to the Acarological Collection of Instituto Butantan (IBSP) for identification. The material previously stored in $70 \%$ alcohol was slide-mounted according to Barros-Battesti et al. (2021) and identified to the genus level using a previously published identification key (Radovsky 2010). In addition, all six original descriptions of Radfordiella species were consulted to obtain species identification.

From this material, 2 females and 9 protonymphs belonging to $R$. desmodi were identified (IBSP 11640). This species can be separated from the other species of the genus mainly because of the presence of two pairs of circular incrassation near the middle of the dorsal shield (in female and male, Fig. 1A) and a rectangular sternal shield (in female and male, Fig. 1B). Also, the females have $\mathrm{Cx}$ II with two subequal spurs (Fig. 1C), while the male has Ge IV with a very short, broad, ventral spur arising distally and opposed to the spur on Fe IV. Besides that, the shape of the pygidial shield with four setae (Fig. 1D) is one of the main characters to separate the protonymphs of $R$. desmodi from the others species. Herein we record $R$. desmodi for the first time in the state of São Paulo, expanding the range distribution of this species, previously found in the states of Mato Grosso do Sul, Minas Gerais, and Rio de Janeiro. The geographical distribution of $R$. desmodi in Brazil is shown in Fig. 2. 

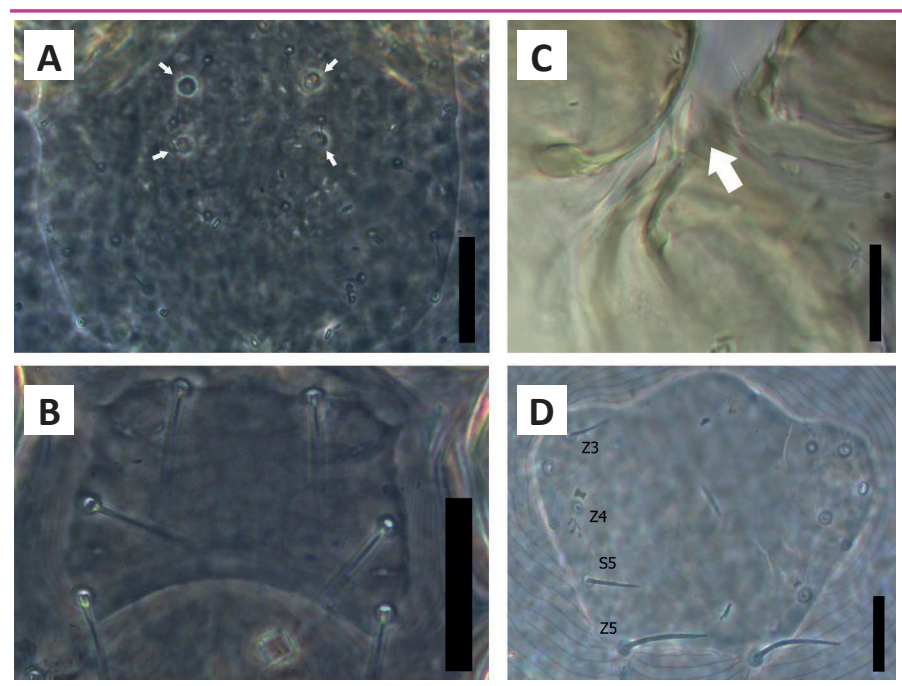

Figure 1. Radfordiella desmodi Radovsky, 1967 (Macronyssidae). A - White arrows indicating the pairs of circular incrassation near the middle of the dorsal shield of a female; B - rectangular sternal shield of a female; C - white arrow indicating the $C x$ II with two subequal spurs of a female; $D$ - pygidial shield with four setae of a protonymph. Scale bar: A and B $50 \mu, C$ and D $20 \mu$.

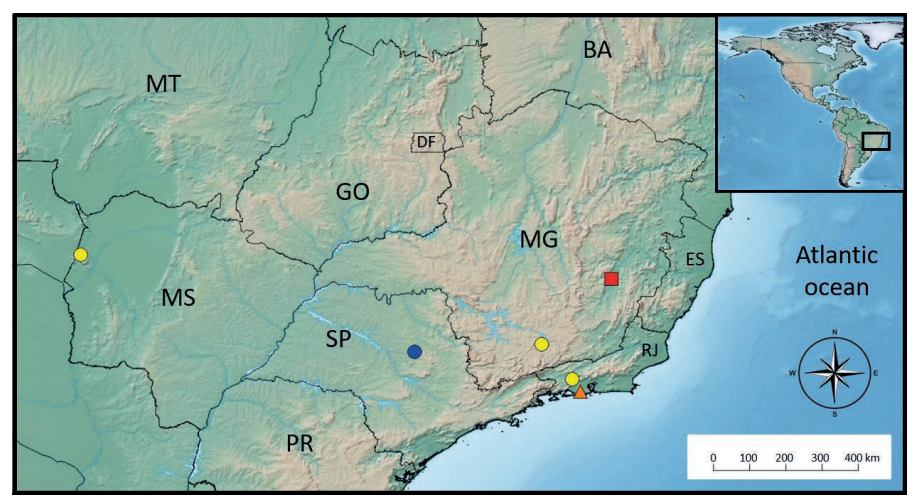

Figure 2. Geographical distribution of Radfordiella desmodi Radovsky, 1967 (Macronyssidae) in bats from Brazil. Each symbol represents the record of a host from which this species was collected: yellow circle - Desmodus rotundus (É. Geoffroy, 1810) (Phyllostomidae); dark blue - new record on D. rotundus; orange triangle - Carollia perspicillata (L., 1758) (Phyllostomidae); red square - Histiotus velatus (I. Geoffroy, 1824) (Vespertilionidae).

Regarding the new record, this represents another record of $R$. desmodi parasitizing $D$. rotundus, further corroborating the possible host specificity of Radfordiella with phyllostomid bats (Saunders 1975). Among the species that are widely known and have all their stages described, $R$. oudemansi is the most generalist of the genus, being found on a few different species of phyllostomid bats. At the same time, $R$. carolliae seems to be a parasite restricted to species within the genus Carollia, and $R$. desmodi seems to parasitize preferably for $D$. rotundus. Up to now, the parasitic preference of the other three species of the genus is not very well known since they were found only once and described based on their nymphal stages.

It is worth noting that there are other records of $R$. desmodi parasitizing other species of phyllostomid bats, but as Saunders (1975) pointed out, these uncommon records are rare and much less frequent, and when they happen, only one or two specimens are found. Besides that, in Brazil, Almeida et al. (2011) identified 24 females and 43 protonymphs on one specimen of $C$. perspicillata, and Moras et al. (2013) only found four females on $H$. velatus. Unfortunately, the focus of these two studies was not taxonomic, since it had a much more ecological or species survey nature since $R$. carolliae parasitizing preferably $C$. perspicillata and not $R$. desmodi, and no other species of this mite genus had been found to parasitize a vespertilionid bat ( $H$. velatus). These very unusual findings raise doubts about their identification, but what can justify such a record is that these mites, on exceptional occasions, can parasitize other species of bats that share the same roosting area (Radovsky 1967).
Thus, the present study provides a new locality for $R$. desmodi and its updated geographic distribution in Brazil.

\section{Acknowledgments}

To Gabrielle Ribeiro de Andrade and Maria Cristina Ferreira do Rosário for technical contribution. This work was supported by Fundação de Amparo à Pesquisa do Estado de São Paulo (FAPESP no. 2017/01416-7, 2018/24667-8 and 2020/11755-6 to RB-S; 2019/198530 to FCJ; 2021/08179-6 to APM). We are also thankful to CNPq (National Council for Scientific and Technological Development) for the Productivity Grant to MRA (CNPq Process \#302420/2017-7). This study was financed in part by the Coordenação de Aperfeiçoamento de Pessoal de Nível Superior - Brasil (CAPES) - Finance Code 001.

\section{Authors' Contributions}

RB-S, APM, FCJ examined the slides and collected the label data and RB-S, APGD, FCJ performed the study and confirmed the identification of the mites. RB-S, FCJ, MRA and DMBB wrote the manuscript with input from all authors.

\section{References}

Almeida, J. C.; Silva, S. P.; Serra-Freire N. M.; Valim, M. P. (2011) Ectoparasites (Insecta and Acari) associated with bats in Southeastern Brazil. Journal of Medical Entomology, 48(4): 753757. doi: 10.1603/ME09133

Azevedo, A. A.; Linardi, P. M.; Coutinho, M. T. Z. (2002) Acari ectoparasites of bats from Minas Gerais, Brazil. Journal of Medical Entomology, 39(3): 553-555. doi: 10.1603/0022-2585-39.3.553

Barros-Battesti, D. M.; Jacinavicius, F. C.; Bauchan, G.; Bassini-Silva, R. (2021) Chapter 24: Techniques for studies on Acariformes. In: Barros-Battesti, D. M.; Machado, R. Z.; André, M. R. (Eds.), Brazilian ectoparasite fauna of veterinary importance, Volume 1 , Mite fauna of veterinary importance: Acariformes, pp. 294-303. Jaboticabal: CBPV.

Bassini-Silva, R.; Jacinavicius, F.C.; Huang-Bastos, M.; Dowling, A. P. G.; Barros-Battesti, D. M. (2021) A checklist of macronyssid species (Mesostigmata: Macronyssidae) from Brazil. Journal of Medical Entomology, 58(2): 625-633. doi: 10.1093/jme/tjaa245

Brass, D. (1994) Rabies in Bats, Natural History and Public Health Implications. Ridgefield, Connecticut: Livia Press.

Colín-Martínez, H.; Morales-Malacara, J. B.; García-Estrada, C. (2018) Epizoic fauna survey on Phyllostomid bats (Chiroptera: Phyllostomidae) in a shaded coffee plantation of Southeastern Chiapas, Mexico. Journal of Medical Entomology, 55(1): 172-182. doi: $10.1093 / \mathrm{jme} / \mathrm{tj} \times 186$

Fonseca, F. (1948) Monograph of the general and species of Macronyssidae Oudemans, 1936 (synom.: Liponyssidae Vitzthum, 1931) (Acari). Proceedings of the Zoological Society of London, 118: 249-334. doi: 10.1111/j.1096-3642.1948.tb00378.x

Gomes-Almeida, B. K.; Pepato, A. R. (2021) A new genus and new species of macronyssid mite (Mesostigmata: Gamasina: Macronyssidae) from Brazilian caves including molecular data and key for genera occurring in Brazil. Acarologia, 61: 501-526. doi: 10.24349/acarologia/20214447

Ikeda, P.; Torres, J. M.; Perles, L.; Lourenço, E. C.; Herrera, M. H.; Oliveira, C. E.; Machado, R. Z.; André, M. R. (2020) Intra- and inter-host assessment of Bartonella diversity with focus on nonhematophagous bats and associated ectoparasites from Brazil. Microorganisms, 8: 1822. doi: 10.3390/microorganisms8111822

Ikeda, P.; Torres, J. M.; Placa, A. J. V.; Mello, V. V. C.; Lourenço, E. C.; Herrera, H. M.; Oliveira, C. E.; Hemsley, C.; Titball, R. W.; Machado, R. Z., et al. (2021) Molecular survey of Anaplasmataceae agents and Coxiellaceae in non-hematophagous bats and associated ectoparasites from Brazil. Parasitologia, 1: 197-209. doi: 10.3390/ parasitologia1040021

Lord, R. (1992) Seasonal reproduction of vampire bats and its relation 
to seasonality of bovine rabies. Journal of Wildlife Diseases, 28(2): 292-294.

Lourenço, E. C.; Gomes, L. A. C.; Viana, A. O.; Famadas, K. M. (2020) Co-occurrence of ectoparasites (Insecta and Arachnida) on bats (Chiroptera) in an Atlantic Forest remnant, Southeastern Brazil. Acta Parasitologica, 65: 750-759. doi: 10.2478/s11686-02000224-z

Moras, L. M.; Bernardi, L. F. O.; Graciolli, G.; Gregorin, R. (2013) Bat flies (Diptera: Streblidae, Nycteribiidae) and mites (Acari) associated with bats (Mammalia: Chiroptera) in a high-altitude region in southern Minas Gerais, Brazil. Acta Parasitologica, 58: 556-563. doi: 10.2478/s11686-013-0179-x

Orlova, M. V.; Kazakov, D. V.; Orlov, O. L.; Mishchenko, V. A.; Zhigalin, A. V. (2017) The first data on the infestation of the parti-coloured bat, Vespertilio murinus (Chiroptera, Vespertilionidae), with gamasid mites, Steatonyssus spinosus (Mesostigmata, Gamasina, Macronyssidae). Russian Journal of Theriology, 16: 66-73. doi: 10.15298/rusjtheriol.16.1.06

Radovsky, F. J.; Jones, J. K.; Phillips, C. J. (1971) Three new species of Radfordiella (Acarina: Macronyssidae) parasitic in the mouth of phyllostomatid bats. Journal of Medical Entomology, 8(6): 737-746. doi: 10.1093/jmedent/8.6.737

Radovsky, F. J. (1967) The Macronyssidae and Laelapidae (Acarina, Mesostigmata) parasitic on bats. University of California publications in entomology, 46: 1-288.

Radovsky, F. J. (2010) Revision of genera of the parasitic mite family Macronyssidae (Mesostigmata: Dermanyssoidea) of the World. West Bloomfield: Indira Publishing House.

Reeves, W. K.; Dowling, A. P. G.; Dasch, G. A. (2006) Rickettsial agents from parasitic Dermanyssoidea (Acari: Mesostigmata). Experimental and Applied Acarology, 38: 181-188. doi: 10.1007/ s10493-006-0007-1

Rojas, A.; Jiménez, A.; Vargas, M.; Zumbado, M.; Herrero, M. V. (2008) Ectoparasites of the common vampire bat (Desmodus rotundus) in Costa Rica: Parasitism rates and biogeographic trends. Mastozoología Neotropical, 15(2): 181-187.

Saunders, S. C. (1975) Venezuelan Macronyssidae (Acarina: Mesostigmata). Brigham Young University Science Bulletin, 20: 7590.

Silva, C. L.; Valim, M. P.; Graciolli. G. (2017) Ácaros ectoparasitos de morcegos no estado de Mato Grosso do Sul, Brasil. Iheringia, 107: 1-6. doi: 10.1590/1678-4766e2017111

Simmons, N.B. (2005) Order Chiroptera. In: Wilson D.E.; Reeder D. M. (Eds.), Mammal Species of the World, pp. 312-529. Baltimore: The Johns Hopkins University Press.

Tarquino-Carbonell, A. P.; Gutiérrez-Díaz, K. A.; Galindo-Espinosa, E. Y.; Reinoso-Flórez, G.; Solari, S.; Guerrero, R. (2015) Ectoparasites associated with bats in northeastern Tolima, Colombia. Mastozoologia Neotropical, 22: 349-358.

Zhang, M.-Y.; Uchikawa, K. (1994) Description of male and protonymph of Nycteronyssus desmodus (Acari: Macronyssidae). Journal of Medical Entomology, 31(2): 315-318. doi: 10.1093/ jmedent/31.2.315 